\title{
Effect of Gum Arabic as Partial Replacement of Cement on the Durability Properties of Compressed Laterite Blocks
}

\author{
Alladjo Rimbarngaye ${ }^{1 *}$, John Nyiro Mwero², Erick Kiplangat Ronoh ${ }^{3}$ \\ ${ }^{1}$ Department of Civil and Construction Engineering, Pan African University Institute for Basic Sciences, Technology and \\ Innovation (PAUSTI) Hosted at Jomo Kenyatta University of Agriculture and Technology, Nairobi, Kenya \\ ${ }^{2}$ Department of Civil and Construction Engineering, University of Nairobi, Nairobi, Kenya \\ ${ }^{3}$ Department of Agricultural and Biosystems Engineering, Jomo Kenyatta University of Agriculture and Technology, \\ Nairobi, Kenya \\ Email: *rimbarngaye.alladjo@students.jkuat.ac.ke
}

How to cite this paper: Rimbarngaye, A. Mwero, J.N. and Ronoh, E.K. (2021) Effect of Gum Arabic as Partial Replacement of Cement on the Durability Properties of Compressed Laterite Blocks. Open Journal of Civil Engineering, 11, 398-410.

https://doi.org/10.4236/ojce.2021.114023

Received: October 15, 2021

Accepted: November 20, 2021

Published: November 23, 2021

Copyright (C) 2021 by author(s) and Scientific Research Publishing Inc. This work is licensed under the Creative Commons Attribution International License (CC BY 4.0)

http://creativecommons.org/licenses/by/4.0/

(c) (i) Open Access

\begin{abstract}
Compressed stabilized earth blocks are the innovation of building materials replacing the earth blocks commonly called adobe. Common stabilizers (cement and lime) have been found to be expensive and harmful to the environment. Finding a natural, available, environmentally friendly stabilizer is vital. The objective of this study was therefore to assess the effects of gum Arabic (GA) as binder on the durability properties of laterite blocks. Compressed laterite blocks were stabilized with $2 \%$ and $6 \%$ respectively as total percentage of binders in the blocks (cement and/or GA). The results showed that GA improved the abrasion and drop resistances of compressed blocks. It has been found that the abrasion resistance of compressed blocks increased with the increase of GA content and the decrease of cement content. For instance, the mass abraded away of blocks stabilized with cement only was reduced up to $95.18 \%$ when GA was used to partially replace cement. As for drop test, the higher the content of GA the higher the resistance of blocks to drop.
\end{abstract}

\section{Keywords}

Gum Arabic, Compressed Stabilised Laterite Blocks, Abrasion Resistance, Earth Block Drop Resistance

\section{Introduction}

Since the first constructions, the earth has been used by man as basic material. 
More than a third of mankind lives in earthen buildings, even in today's super-modern world of the 21 st century. Earthen structures are better adapted to the climate, more environmentally friendly, more accessible and affordable for all, and offer a very primitive cultural link to nature [1]. However, these earthen structures made of earth blocks have a number of issues (durability problems), including rain erosion, spalling, cross-section reduction, cracking at low compressive and tensile strengths, shrinkage, low strength, and dimensional stability [2] [3] [4] [5]. Typically, in order to remedy these problems and build sustainable structures, various conventional additives such as lime, fly ash and cement have been added to soils for soil stabilization [6]. Of the above-mentioned materials, cement is the most widely used. Unfortunately, these techniques contribute to the destruction of the environment through the emission of greenhouse gases and especially through the fact that they are non-renewable materials and are even not accessible to everyone [1] [6] [7]. It has been demonstrated that compressed stabilised earth blocks (CSEB) generate $22 \mathrm{~kg} \mathrm{CO}_{2} /$ tonne, concrete blocks $143 \mathrm{~kg} \mathrm{CO} /$ tonne, fired clay bricks $200 \mathrm{~kg} \mathrm{CO}_{2} /$ tonne [8]. It was also demonstrated that during the production of the CSEB, $1 \mathrm{~kg}$ of cement used emits 0.894 $\mathrm{kg}$ of $\mathrm{CO}_{2}$ [9] [10]. In order to reduce the negative environmental impacts of cement and use environmentally friendly materials, the use of natural biopolymers has been proposed as an alternative in soil stabilization [11] [12] [13]. In addition, some research has also been carried out on certain gums for soil stabilisation, mainly xanthan gum, gellan gum, agar gum, polyacrylamide and guar gum [6].

Very recent studies have shown the suitability of using gum Arabic (GA) in concrete. GA has been shown to have low viscosity and high-water solubility [14]. Because of its attractive properties, it is used in various industries including cosmetics, textiles, pharmaceuticals, encapsulation, lithography and even the food industry. GA has also been used as an additive in a binder for ceramic glazes to reduce the risk of damage during factory handling [15]. Studies have also shown that the addition of GA to concrete has improved the properties of concrete due to the presence of minerals such as sepiolite, palygorskite and mordenite. The compressive strengths of concrete containing GA increased with the dosage of $\mathrm{GA}$, and this dosage range of $0.50 \%-0.75 \%$ is adequate for use [16]. On the other hand, it has been shown that GA at a dosage level of $0.8 \%$ by weight of cement is a dual function concrete admixture, namely a setting accelerator (SA) and a normal water reducer (WR) according to BS EN 934-2 (2009) [17]. It reduces water by $11.5 \%$ without altering the consistency of a reference concrete mix [17]. Furthermore, GA has also shown its suitability in concrete as superplasticizer in self-compacting concrete at a dosage of $8 \%$ by the weight of cement for water-powder ratio of 1.0, 0.9 and 0.8 [18]. Used as a water reducing admixture in cement mortar, GA has also shown its suitability as a retarding admixture in mortar at temperatures between $23^{\circ} \mathrm{C}$ and $25^{\circ} \mathrm{C}$ [19]. In addition, GA has also shown its suitability as a binder in partial replacement of cement in the fabrica- 
tion of micro-concrete tiles [20] and the production of panels made from sawdust and wood shavings [21].

In the field of soil, there is some research that has been conducted on the use of natural ingredients for earth construction. This research has been based on the oral tradition of ancestors transmitted from one generation to another [1]. Among these natural ingredients is GA. A few lab tests were carried out to show the importance of using these natural materials in earthen constructions. From these studies, which were limited only to erosion and abrasion tests, it was recommended to do more research on these natural ingredients in order to show the performance of using them in the stabilisation of earthen materials [1].

Water is the main challenge to the durability of earthen blocks [5]. Therefore, the aim of stabilisation is to minimise the destruction of earthen blocks by water in order to use materials that can limit the loss of block strength in a wet state [5] [8]. Stabiliser content, clay content and compaction strength influence the durability of blocks [8]. It has been observed that the fall of material from the surface of wall panels is caused by the kinetic energy released by raindrops hitting the blocks [22].

The determination of the durability of blocks is difficult and is not frequent [23]. However, there are several tests that can predict the durability of materials. These tests are grouped into three types: accelerated tests (spray test, drip test, rainfall test, slake test), indirect tests (wire brush test, wet-dry strength ratio test, capillarity water absorption test, total water absorption test, water absorption test under static pressure, free-thaw cycle test) and simulation tests [5]. In addition to these tests, there is also the drop test established by the standard [24] which allows the durability of blocks subjected to free fall to be assessed. Accelerated and indirect durability tests are known to be very severe compared to the natural conditions to which the blocks might be exposed [1] [8], especially for biopolymer-based stabilised blocks [1]. Thus, the block drop test established by the standard [24] would be suitable for testing the durability of blocks.

This article presents the experimental work carried out to show the potential use of GA to improve the durability performance of compressed stabilized laterite blocks. As a result, this shows findings that can lead to further research and can also help people to use GA in the field of construction.

\section{Materials and Methods}

\subsection{Materials}

The study was conducted at the Civil Engineering Laboratory of the Jomo Kenyatta University of Agriculture and Technology (JKUAT), Kenya ( $1^{\circ} 5^{\prime} 45^{\prime \prime} \mathrm{S}$ and $37^{\circ} 0^{\prime} 44$ "E for latitude and longitude, respectively). The materials used in this research were GA, laterite soil, river sand, cement and water.

The GA used in this research was obtained locally in Kenya. It was supplied from Isiolo, a county in central Kenya. The laterite soil used in this study was acquired locally in Juja, within JKUAT. The sand used in this research was sup- 
plied from Meru, a town in eastern Kenya. The cement used in this study was pozzolanic cement type CEM IV/32.5R which complies with the Kenyan standards in force (KS EAS 18-1:2001). The source of water used for mixing different materials (cement, soil, sand, GA), curing and various tests was the potable water without impurities supplied from the university system (JKUAT). It complied with the Kenyan water regulations (KS EAS 12, 2014).

\subsection{Preparation of the Solution of GA}

After measuring the quantities of GA required for each percentage for the different types of blocks with a balance, these quantities of GA in powder form were dissolved with a quantity of water previously determined during the compaction test to obtain the optimum moisture content (OMC) for maximum dry density (MDD) (Figure 1). These dissolved gum solutions were left for 24 hours to ensure complete dissolution of the GA in the water. To avoid confusion between the different percentages of GA, each bucket containing a given percentage of GA was marked with that percentage using a marker as shown in Figure 1. The resulting solution was sticky and this was then mixed with soil for block production [25].

\subsection{Blocks Production}

As shown in Figure 2, the production of the blocks is summarized in five main steps [25]. The first was the preparation of the soil, that is, the soil was sieved on a $5 \mathrm{~mm}$ sieve as recommended [26] and then put into bags and transported to the laboratory, then comes the second step which consists of mixing the laterite soil with different proportions of binders, sand and water (Table 1). The amount of water used is the OMC determined during the compaction test on different percentages of GA. It is important to highlight that the natural moisture content of the soil was deducted from the optimum moisture content in order to obtain the precise amount of water for the mix. Then, the third step was the production of the blocks using the manual press machine. In this step, the mould of the press machine was lubricated with drain oil. Then, the homogeneous mixture of
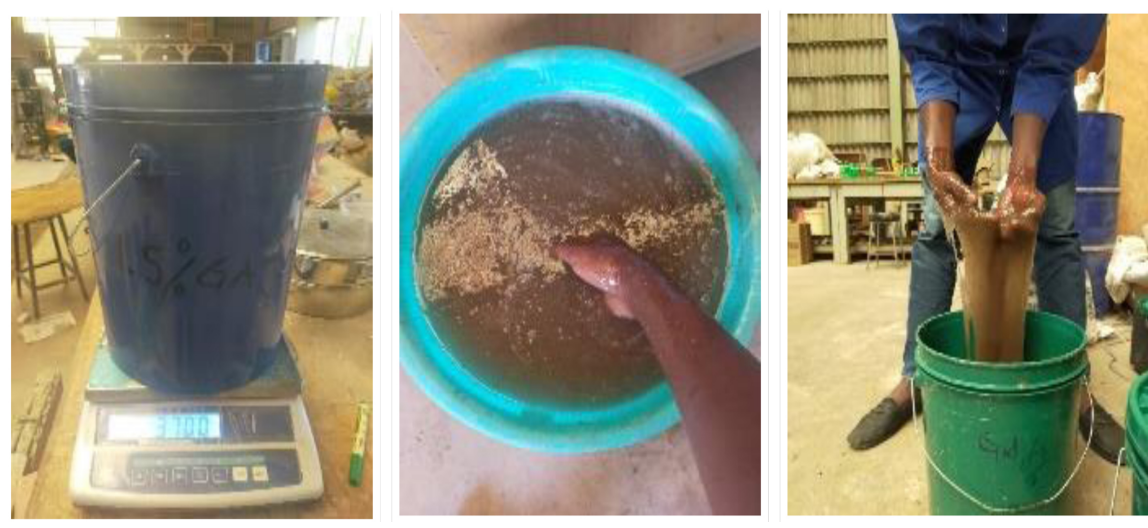

Figure 1. Preparation of the solution of GA [25]. 


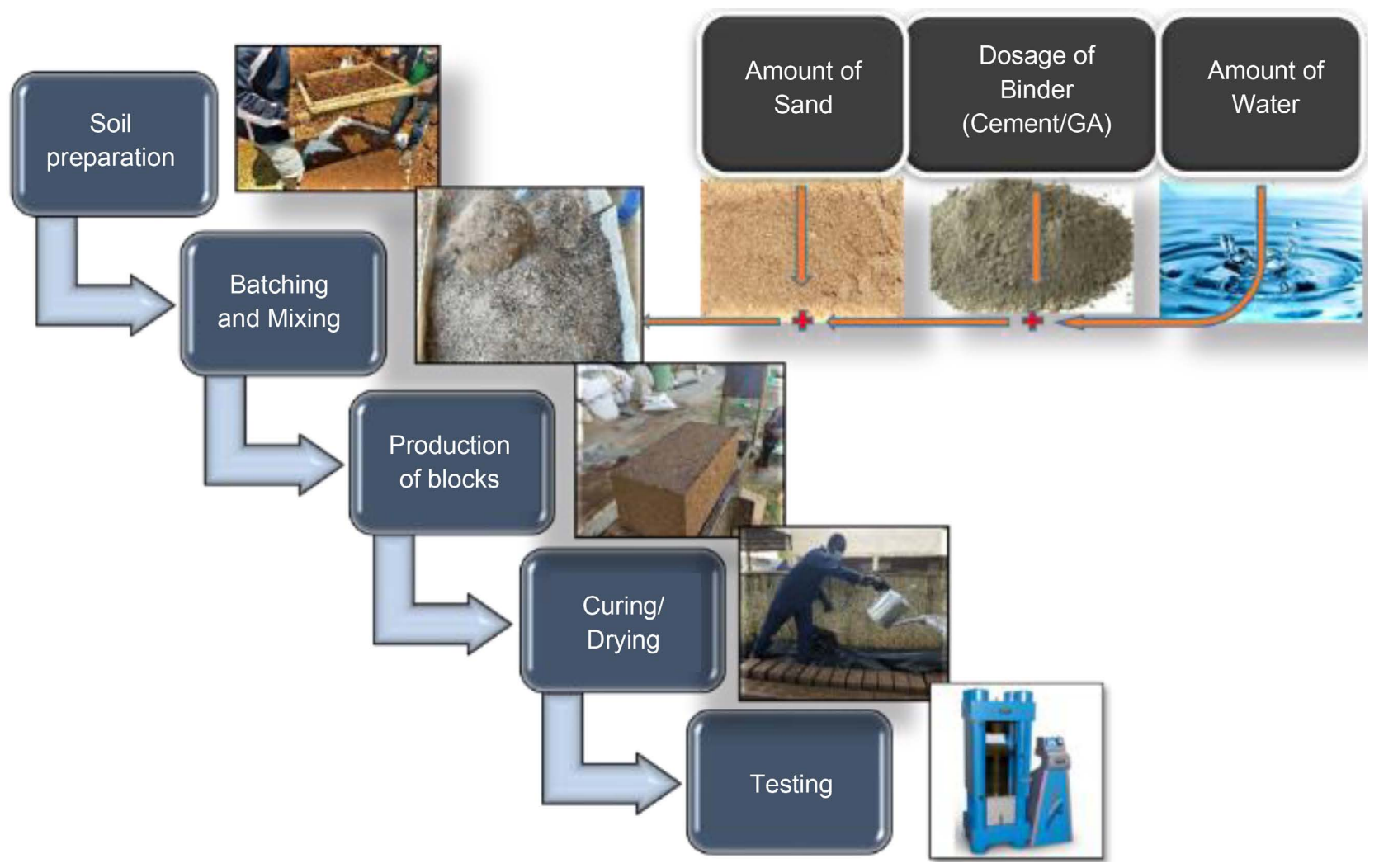

Figure 2. Block production process [25].

Table 1. Mix proportion of compressed stabilised laterite blocks.

\begin{tabular}{|c|c|c|c|c|c|}
\hline Soil type & \multicolumn{5}{|c|}{ Production of blocks for obtaining the optimum cement content for replacement } \\
\hline & \multicolumn{5}{|c|}{ Replacement for $2 \%$ of cement } \\
\hline & \multicolumn{2}{|c|}{ Binder } & \multirow{2}{*}{ Sand } & \multirow{2}{*}{ Water } & \multirow{2}{*}{ Code } \\
\hline & Cement & Gum Arabic (GA) & & & \\
\hline & $2 \%$ & $0 \%$ & Fixed & OMC & $2 \%+0 \% \mathrm{GA}$ \\
\hline & $1.5 \%$ & $0.5 \%$ & Fixed & OMC & $1.5 \% \mathrm{C}+0.5 \% \mathrm{GA}$ \\
\hline & $1 \%$ & $1 \%$ & Fixed & OMC & $1 \% \mathrm{C}+1 \% \mathrm{GA}$ \\
\hline & $0.5 \%$ & $1.5 \%$ & Fixed & OMC & $0.5 \% \mathrm{C}+1.5 \% \mathrm{GA}$ \\
\hline \multirow{9}{*}{ Laterite } & $0 \%$ & $2 \%$ & Fixed & $\mathrm{OMC}$ & $0 \% \mathrm{C}+2 \% \mathrm{GA}$ \\
\hline & \multicolumn{5}{|c|}{ Replacement for $6 \%$ of cement } \\
\hline & \multicolumn{2}{|c|}{ Binder } & \multirow{2}{*}{ Sand } & \multirow{2}{*}{ Water } & \multirow{2}{*}{ Code } \\
\hline & Cement & Gum Arabic (GA) & & & \\
\hline & $6 \%$ & $0 \%$ & Fixed & OMC & $6 \%+0 \% \mathrm{GA}$ \\
\hline & $4.5 \%$ & $1.5 \%$ & Fixed & OMC & $4.5 \% \mathrm{C}+1.5 \% \mathrm{GA}$ \\
\hline & $3 \%$ & $3 \%$ & Fixed & $\mathrm{OMC}$ & $3 \% \mathrm{C}+3 \% \mathrm{GA}$ \\
\hline & $1.5 \%$ & $4.5 \%$ & Fixed & OMC & $1.5 \% \mathrm{C}+4.5 \% \mathrm{GA}$ \\
\hline & $0 \%$ & $6 \%$ & Fixed & OMC & $0 \% \mathrm{C}+6 \% \mathrm{GA}$ \\
\hline
\end{tabular}


soil with the obtained binder was loaded into the mould of the manual press machine and the mould cover put back in place. Finally, the block was pressed and ejected. In step four, after manufacture, the blocks were stored under cover and covered with polystyrene for 24 hours. After 24 hours, they were watered and covered once more with polythene sheet for 6 days before the polythene sheet was removed. After this curing period, the blocks were ready for testing.

\subsection{Abrasion Test (Wear Method)}

The abrasion test is used to assess the durability of laterite blocks partially stabilised with GA. Before starting the abrasion test, each block sample was weighed. Then the block was placed on a horizontal plane and held in such a way as to avoid slipping (Figure 3). A wire brush is used to scrub the face of the test sample. A single back and forth movement of the brush is considered one cycle of abrasion. 20 cycles of abrasion are applied to each block, after which the block is reweighed [1]. The abrasion value $\alpha(\%)$ was determined using Equation (1), where $W_{b}$ is the weight of the block before abrasion and $W_{a}$ is the weight of the block after abrasion.

$$
\alpha=\frac{\left(W_{b}-W_{a}\right)}{W_{b}} \times 100
$$
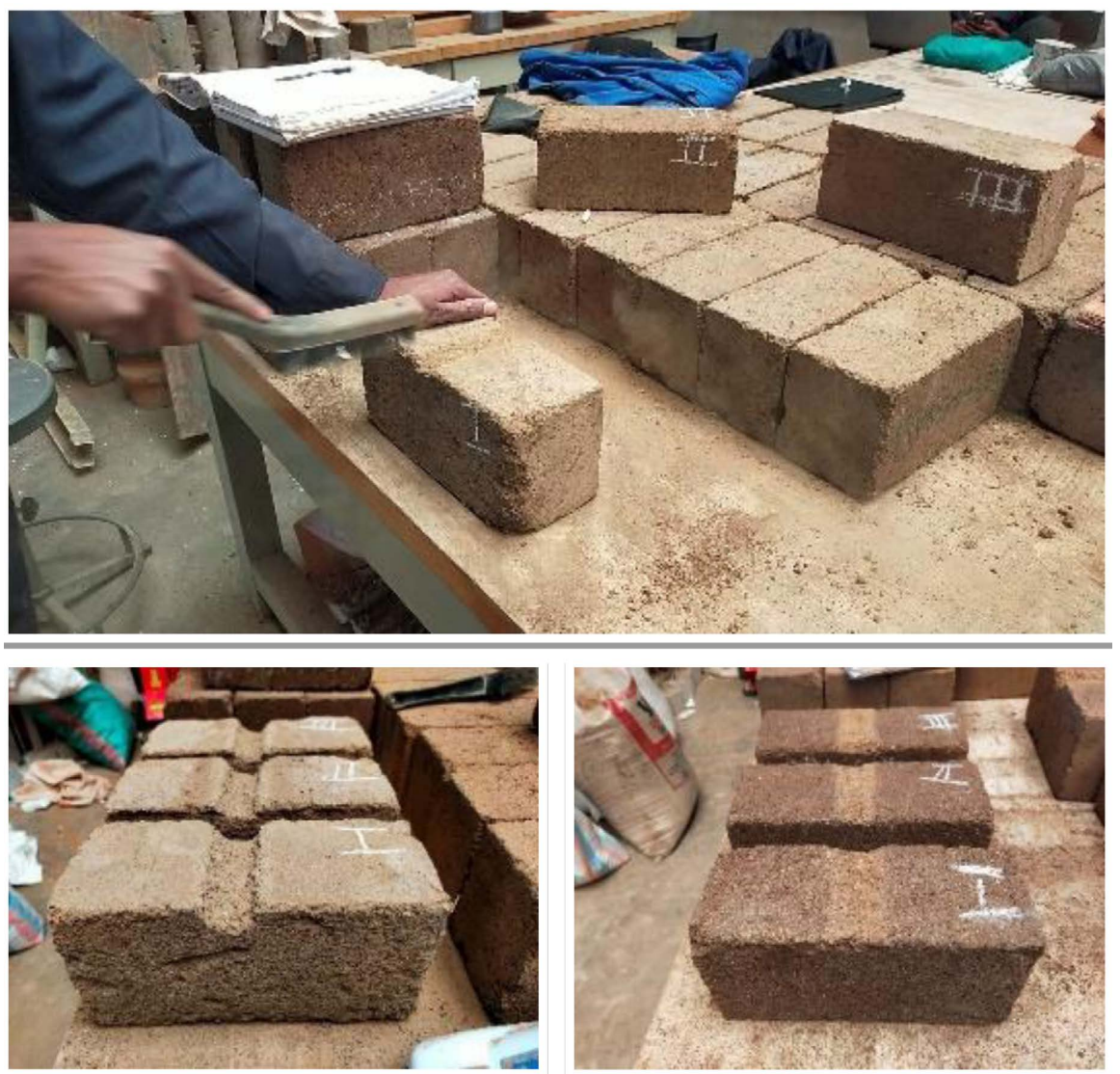

Figure 3. Conducting an abrasion test on the blocks. 


\subsection{Earth Block Drop Test}

The block drop test was carried out for both 28- and 56-day old blocks. The test was conducted in accordance with New Zealand Standard [24]. In this test the block is held as shown in Figure 4(a) and dropped with its lowest point $900 \mathrm{~mm}$ above the point of impact on the concrete floor. The block is assumed to be satisfactory if it does not break into pieces of approximately equal size and if it is not missing $100 \mathrm{~mm}$ or more from any corner of the largest remaining piece.

\section{Results and Discussion}

\subsection{Abrasion Resistance of Compressed Stabilized Laterite Blocks Using $2 \%$ and $6 \%$ as Total Percentage of Binders in the Blocks and Replacing Cement with GA}

The results of the block abrasion test obtained by partially replacing the cement with GA ( $2 \%$ and $6 \%$ as the total percentage of binders in the block) are presented in Figure 5.

Taking $2 \%$ as the total percentage of stabilizers (cement and/or GA) and partially or totally replacing cement with GA, the results show that in general the
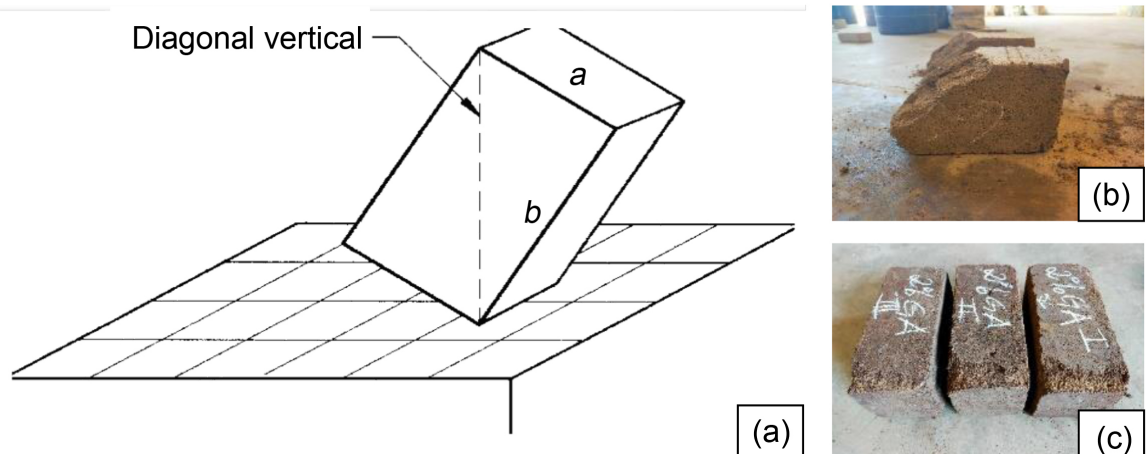

(a)

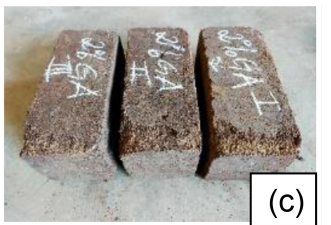

Figure 4. Conducting the earth block drop test: (a) disposition of the blocks during the test; (b) impact of blocks stabilized with cement; (c) impact of blocks stabilized with GA.

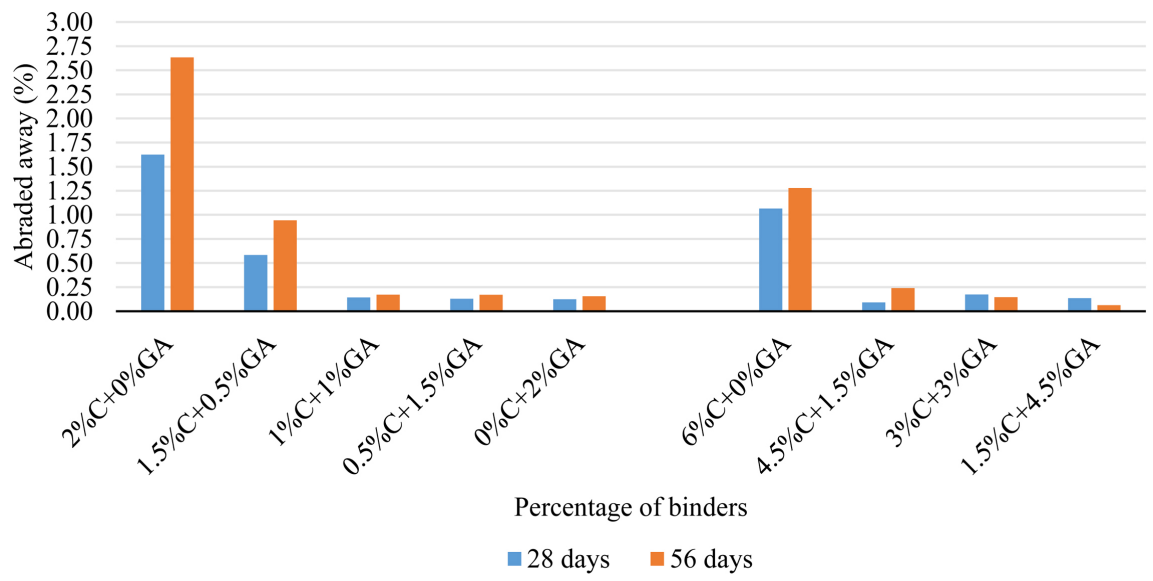

Figure 5. Abrasion resistance of stabilised laterite blocks using GA as partial replacement of cement. 
blocks with GA presented a higher abrasion resistance than the control blocks $(2 \% \mathrm{C}+0 \% \mathrm{GA})$. On the other hand, it can be noticed that the abrasion resistance decreases with the age of the blocks. In addition, it is important to note that the abrasion resistance of the blocks increases gradually with the increase of the percentage of GA in the cement replacement for all ages. Thus, at 28 days, there is a reduction in abrasion of $64.13 \%, 91.27 \%, 92.12 \%$ and $92.42 \%$ for the blocks $(1.5 \% \mathrm{C}+0.5 \% \mathrm{GA}),(1 \% \mathrm{C}+1 \% \mathrm{GA}),(0.5 \% \mathrm{C}+1.5 \% \mathrm{GA})$ and $(0 \% \mathrm{C}+2 \% \mathrm{GA})$, respectively, compared to the control blocks $(2 \% \mathrm{C}+0 \% \mathrm{GA})$. At 56 days, the reduction in abrasion is $64.14 \%, 93.50 \%, 93.55 \%$ and $94.14 \%$ for the $(1.5 \% \mathrm{C}+$ $0.5 \% \mathrm{GA}),(1 \% \mathrm{C}+1 \% \mathrm{GA}),(0.5 \% \mathrm{C}+1.5 \% \mathrm{GA})$ and $(0 \% \mathrm{C}+2 \% \mathrm{GA})$ blocks, respectively, compared to the control blocks $(2 \% \mathrm{C}+0 \% \mathrm{GA})$.

Using $6 \%$ as the total percentage of binders in the blocks (cement and/or GA) and replacing partially the cement with GA, the results also showed that GA has an abrasion reducing effect on the blocks. Thus, the blocks partially stabilised with GA and cement have a higher abrasion resistance than the control blocks stabilised with cement only. Also, in general, this abrasion resistance increases with increasing GA content and reducing cement content. In other words, when cement content is increased and GA content is reduced, the blocks are less resistant to abrasion. At 28 days, a reduction in abrasion of $91.43 \%, 83.73 \%$ and $87.31 \%$ can be observed for the blocks $(4.5 \% \mathrm{C}+1.5 \% \mathrm{GA}),(3 \% \mathrm{C}+3 \% \mathrm{GA})$ and $(1.5 \% \mathrm{C}+4.5 \% \mathrm{GA})$, respectively, compared to the control blocks $(6 \% \mathrm{C}+0 \% \mathrm{GA})$. At 56 days, the reduction in abrasion is $81.28 \%, 88.66 \%$ and $95.18 \%$ for the blocks $(4.5 \% \mathrm{C}+1.5 \% \mathrm{GA}),(3 \% \mathrm{C}+3 \% \mathrm{GA})$ and $(1.5 \% \mathrm{C}+4.5 \% \mathrm{GA})$, respectively, compared to the control blocks $(6 \% \mathrm{C}+0 \% \mathrm{GA})$.

Thus, it can be clearly seen that GA has an abrasion reducing effect on the blocks. This is interesting because it contributes to the durability of the blocks. This effect of GA in contributing to the durability of the materials was also confirmed by [27] [28]. It is probably for this reason that the results of the block drop test were better for the blocks with GA compared to the control blocks. This is because GA is able to increase the cohesion of the different soil particles [29], thus enhancing the performance of the material and its shock resistance. Therefore, it has been observed that blocks containing GA have better edge stability compared to the cement-only stabilised control blocks, as illustrated in Figure 6. In addition, when rubbing these blocks with the hand, there is a feeling that they do not degrade as compared to the cement-only control blocks.

\subsection{Earth Block Drop Test Results of Compressed Stabilized Laterite Blocks Using $2 \%$ and $6 \%$ as Total Percentage of Binders in the Blocks and Replacing Cement with GA}

The results of drop test are presented in Table 2 and Table 3. As shown in Table 2 for $2 \%$ binders, by partially replacing the cement with GA, only two blocks failed to meet the requirements of the New Zealand Standard [24], all other blocks performed satisfactorily. In the case of $6 \%$ binder, all blocks met the 


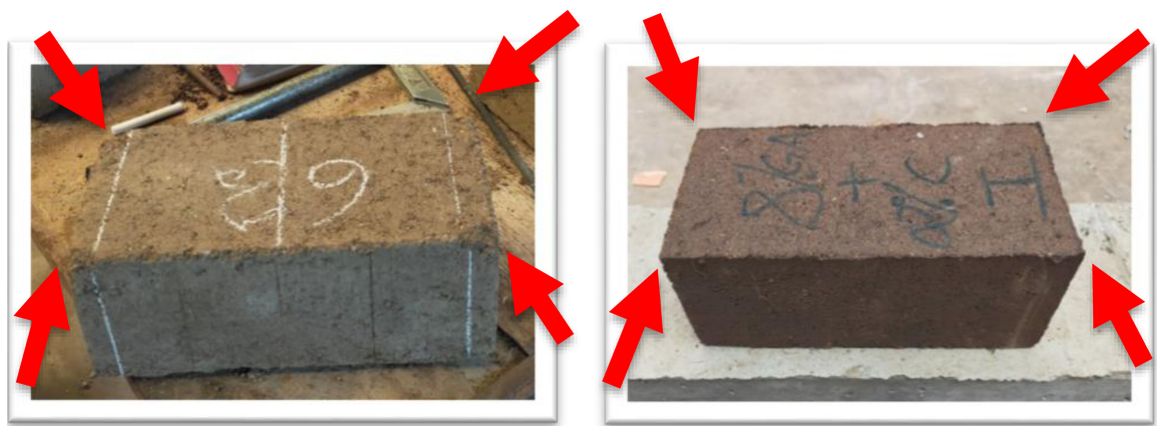

Figure 6. Pictures showing the edges of the blocks without GA (on left) and with GA (on right).

Table 2. Drop test of blocks after replacement of cement by GA using $2 \%$ as the total percentage of binders in the blocks.

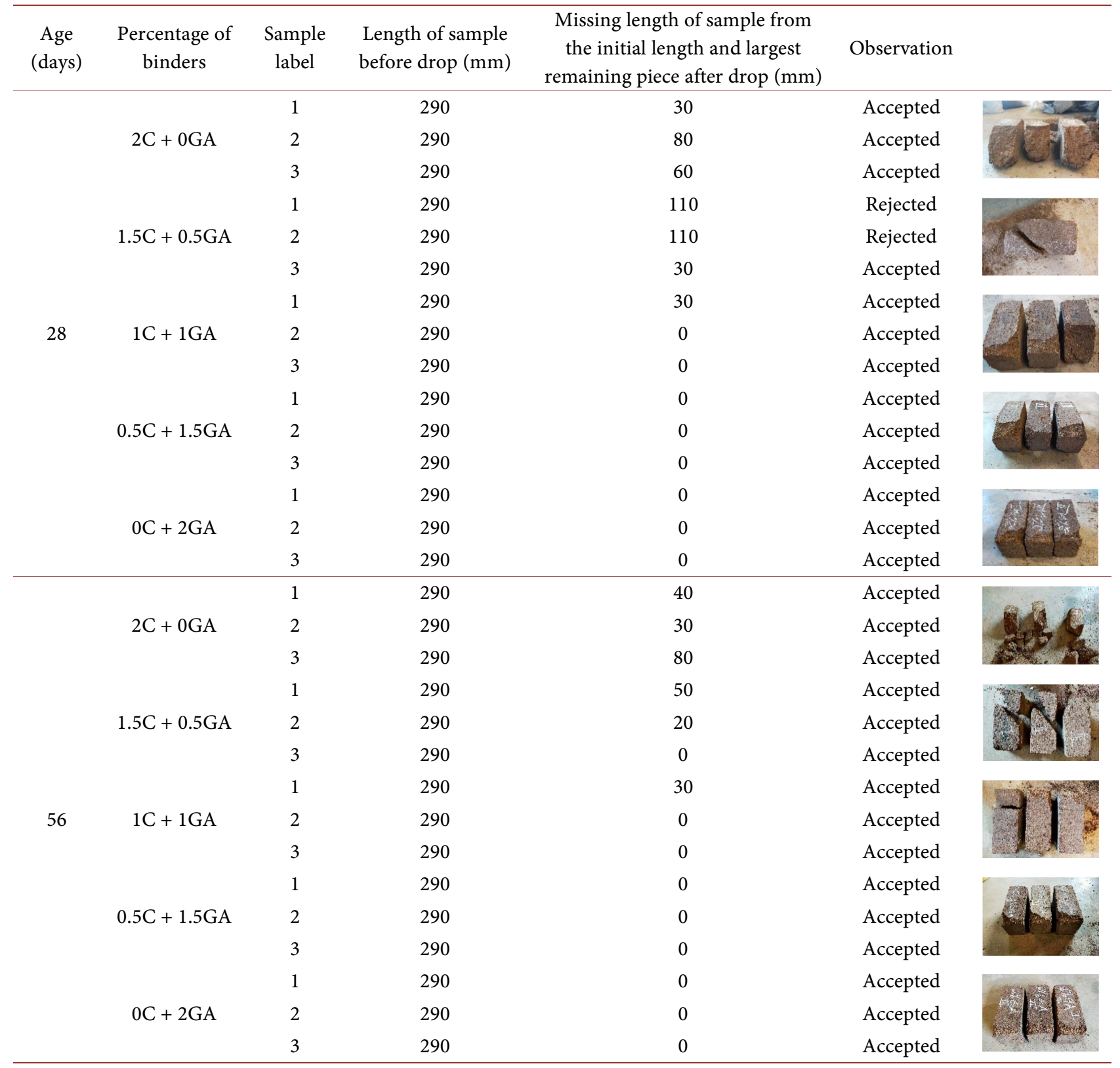


Table 3. Drop test of blocks after replacement of cement by GA using $6 \%$ as the total percentage of binders in the blocks.

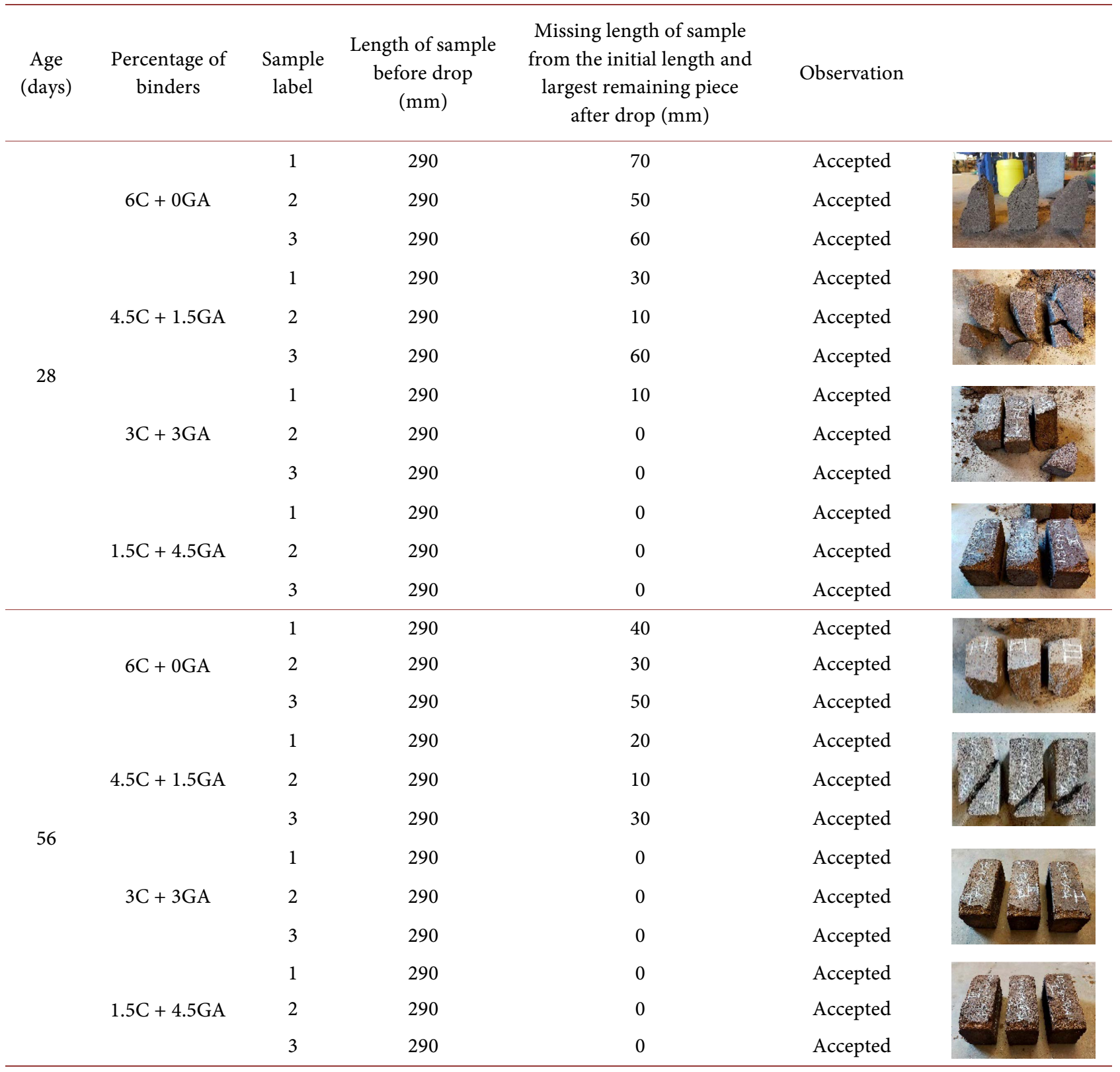

requirements of the New Zealand Standard [24] (Table 3). It is also important to note that the drop resistance of the blocks increases with increasing GA content and reducing cement content. In addition, it should be noted that when the cement content is higher than GA content, the blocks broke into two parts obliquely at an angle of about $45^{\circ}$ when they fell. On the other hand, for blocks with an Arabic gum content equal to or higher than that of the cement, when falling, the blocks did not break in the same way as blocks with an Arabic gum content lower than that of the cement. For these blocks, only the edges disintegrated on contact with the floor. This is observed for both types of partial replacement of cement with GA ( $2 \%$ and $6 \%$ as total percentage of binders in the blocks). Thus, 
this observation is interesting and blocks stabilised with GA have an advantage over blocks stabilised with cement only because they could better resist shocks in the construction of buildings. For this very reason, it was also found that these blocks showed good resistance to the abrasion test.

These good results can be explained by the fact that GA has the ability to rigorously consolidate soil particles together [29] [30] [31]. This consolidation of the different soil particles is achieved through the phenomenon of hydrogel. In the presence of water, GA likely forms a hydrogel thinner than the soil particles and the cement capable of penetrating the pores of the different particles of the block. It is this phenomenon that gives GA a good emulsifying property [32]. In addition, it has been proven that when GA is mixed with cement, during hydration a huge amount of Calcium Silicate Hydrate is formed, responsible for stabilising and obtaining good performance of the blocks [27] [28].

\section{Conclusion}

This paper presented the experimental work on the abrasion and drop of compressed laterite blocks stabilized with gum Arabic as partial replacement of cement. From the results, it has been found that the abrasion resistance of compressed blocks stabilized with GA increased with the increase in GA content and with the decrease in cement content. The mass abraded away of blocks stabilized with cement only was reduced up to $95.18 \%$ when GA was used to partially replace cement. From the drop test, the compressed blocks stabilized with GA as partial replacement of cement showed a good resistance to drop. Kindly replace this sentence with the following: the drop resistance of the blocks increases with increasing gum Arabic content and reducing cement content. Therefore, the results obtained in this study show that GA can indeed improve the performance of blocks when used as a partial replacement of cement.

\section{Acknowledgements}

The authors would like to express their gratitude to the African Union Commission (AUC) and Japan International Cooperation Agency (JICA) for their support of this research.

\section{Conflicts of Interest}

The authors declare no conflicts of interest regarding the publication of this paper.

\section{References}

[1] Reddy, B.V.V., Mani, M. and Walker, P. (2019) Earthen Dwellings and Structures. 1st Edition, Springer, Singapore. https://doi.org/10.1007/978-981-13-5883-8

[2] Miccoli, L., Müller, U. and Fontana, P. (2014) Mechanical Behaviour of Earthen Materials: A Comparison between Earth Block Masonry, Rammed Earth and Cob. Construction and Building Materials, 61, 327-339. 
https://doi.org/10.1016/j.conbuildmat.2014.03.009

[3] Danso, H., Martinson, B., Ali, M. and Mant, C. (2014) Performance Characteristics of Enhanced Soil Blocks: A Quantitative Review. Building Research \& Information, 43, 253-262. https://doi.org/10.1080/09613218.2014.933293

[4] Sharma, V., Marwaha, B.M. and Vinayak, H.K. (2016) Enhancing Durability of Adobe by Natural Reinforcement for Propagating Sustainable Mud Housing. International Journal of Sustainable Built Environment, 5, 141-155. https://doi.org/10.1016/j.ijsbe.2016.03.004

[5] Medvey, B. and Dobszay, G. (2020) Durability of Stabilized Earthen Constructions: A Review. Geotechnical and Geological Engineering, 38, 2403-2425. https://doi.org/10.1007/s10706-020-01208-6

[6] Jang, J. (2020) A Review of the Application of Biopolymers on Geotechnical Engineering and the Strengthening Mechanisms between Typical Biopolymers and Soils. Advances in Materials Science and Engineering, 2020, Article ID: 1465709. https://doi.org/10.1155/2020/1465709

[7] Patel, M. (2015) Review on Partial Replacement of Cement in Concrete. UKIERI Concrete Congress on Concrete Research Driving Profit and Sustainability, Jalandhar, November 2015, 830-837.

[8] Riza, F.V., Rahman, I.A., Mujahid, A. and Zaidi, A. (2010) A Brief Review of Compressed Stabilized Earth Brick (CSEB). CSSR 2010-2010 International Conference on Science and Social Research, Kuala Lumpur, 5-8 December 2010, 999-1004.

[9] Peng, C. (2015) Calculation of a Building's Life Cycle Carbon Emissions Based on Ecotect and Building Information Modeling. Journal of Cleaner Production, 112, 453-465. https://doi.org/10.1016/j.jclepro.2015.08.078

[10] Hoff, E.C. (2016) Appraisal of the Sustainability of Compressed Stabilized Earthen Masonry. University of Nebraska, Lincoln.

[11] Jeong, M.S., Noh, D., Hong, E., Lee, K.S. and Kwon, T. (2019) Systematic Modeling Approach to Selective Plugging Using in Situ Bacterial Biopolymer Production and Its Potential for Microbial-Enhanced Oil Recovery. Geomicrobiology Journal, 36, 468-481. https://doi.org/10.1080/01490451.2019.1573277

[12] Lee, S., Im, J., Cho, G.C. and Chang, I. (2019) Laboratory Triaxial Test Behavior of Xanthan Gum Biopolymer-Treated Sands. Geomechanics and Engineering, 17, 445-452. https://doi.org/10.12989/gae.2019.17.5.445

[13] Tran, A.T.P., Chang, I. and Cho, G.C. (2019) Soil Water Retention and Vegetation Survivability Improvement Using Microbial Biopolymers in Drylands. Geomechanics and Engineering, 17, 475-483.

[14] Randall, R.C., Phillips, G.O. and Williams, P.A. (1988) The Role of the Proteinaceous Component on the Emulsifying Properties of Gum Arabic. Food Hydrocolloids, 2, 131-140. https://doi.org/10.1016/S0268-005X(88)80011-0

[15] Verbeken, D., Dierckx, S. and Dewettinck, K. (2003) Exudate Gums: Occurrence, Production, and Applications. Applied Microbiology and Biotechnology, 63, 10-21. https://doi.org/10.1007/s00253-003-1354-Z

[16] Elinwa, A.U., Abdulbasir, G. and Abdulkadir, G. (2018) Gum Arabic as an Admixture for Cement Concrete Production. Construction and Building Materials, 176, 201-212. https://doi.org/10.1016/j.conbuildmat.2018.04.160

[17] Satti, S.A.A. and Ahmed, Y.H. (2018) Use of Gum Arabic (Acacia Seyal) as Concrete Admixture. 2nd Conference Proceedings of Civil Engineering, Khartoum, December 2018, 198-202. 
[18] Athman, C.M., Abuodha, S.O. and Nyomboi, T. (2018) Use of Gum Arabic as a Superplasticizer in Self-Compacting Concrete. International Journal of Innovative Science and Modern Engineering, 5, 8-13.

[19] Mbugua, R., Salim, R. and Ndambuki, J. (2016) Effect of Gum Arabic Karroo as a Water-Reducing Admixture in Cement Mortar. Case Studies in Construction Materials, 5, 100-111. https://doi.org/10.1016/j.cscm.2016.09.002

[20] Bozabe, R.K., Toukourou, C.A. and Gbaguidi, G.A. (2013) Étude des caractéristiques physico-mécaniques des tuiles en micro-béton fabriquées localement à base de la gomme arabique Résumé. Afrique Science, 9, 1-15.

[21] Ndububa, E. (2013) Performance Characteristics of Gum Arabic Bonded Particleboard Made from Sawdust and Wood Shavings. Ife Journal of Technology, 22, 5-8.

[22] Heathcote, K.A. (1995) Durability of Earthwall Buildings. Construction and Building Materials, 9, 185-189. https://doi.org/10.1016/0950-0618(95)00035-E

[23] Silva, M.F.C.G. (2015) Compressed Earth Blocks with and without Cementitious Materials. pp. 1-13.

https://fenix.tecnico.ulisboa.pt/downloadFile/563345090414497/Compressed\%20ear th\%20blocks\%20with\%20and\%20without\%20cementitous\%20materials.pdf

[24] Standards New Zealand (1998) NZS 4298: Materials and Workmanship for Earth Buildings. Standards New Zealand, Wellington.

[25] Rimbarngaye, A., Mwero, J.N. and Ronoh, E.K. (2021) Performance Evaluation of Compressed Laterite Blocks Stabilized with Cement and Gum Arabic. International Journal of Advanced Technology and Engineering Exploration, 8, 1268-1278. https://doi.org/10.19101/IJATEE.2021.874536

[26] Uzoegbo, H.C. (2016) 8. Dry-Stack and Compressed Stabilised Earth-Block Construction. In: Harries, K. and Sharma, B., Eds., Nonconventional and Vernacular Construction Materials, Woodhead Publishing, Sawston, 205-249.

https://doi.org/10.1016/B978-0-08-100038-0.00008-1

[27] Mohamed, A.M., Osman, M.H., Smaoui, H. and Mohd Ariffin, M.A. (2017) Permeability and Tensile Strength of Concrete with Arabic Gum Biopolymer. Advances in Civil Engineering, 2017, Article ID: 4703841. https://doi.org/10.1155/2017/4703841

[28] Mohamed, A.M., Osman, M.H., Smaoui, H. and Mohd Ariffin, M.A. (2018) Durability and Microstructure Properties of Concrete with Arabic Gum Biopolymer Admixture. Advances in Civil Engineering, 2018, Article ID: 1962832. https://doi.org/10.1155/2018/1962832

[29] Muguda, S., Booth, S.J., Hughes, P.N. and Augarde, C.E. (2017) Mechanical Properties of Biopolymer-Stabilised Soil-Based Construction Materials. Géotechnique Letters, 7, 309-314. https://doi.org/10.1680/jgele.17.00081

[30] Ayeldeen, M., Negm, A., El-Sawwaf, M. and Kitazume, M. (2017) Enhancing Mechanical Behaviors of Collapsible Soil Using Two Biopolymers. Journal of Rock Mechanics and Geotechnical Engineering, 9, 329-339. https://doi.org/10.1016/j.jrmge.2016.11.007

[31] Chang, I., Im, J., Prasidhi, A.K. and Cho, G. (2015) Effects of Xanthan Gum Biopolymer on Soil Strengthening. Construction and Building Materials, 74, 65-72. https://doi.org/10.1016/j.conbuildmat.2014.10.026

[32] Mariod, A.A. (2018) 12. Enhancement of Color Stability in Foods by Gum Arabic. In: Maragioglio, N., Ed., Gum Arabic, Academic Press, Cambridge, 143-150. https://doi.org/10.1016/B978-0-12-812002-6.00012-9 